\title{
CLINICAL PROFILE OF CHILDREN WITH DOWN SYNDROME TREATED IN A GeNetics OUtPATIENT SERVICE IN THE SOUtheAst OF BRAZIL
}

\author{
Érika Cristina Pavarino Bertelli ${ }^{1 *}$, Joice Matos Biselli², Daiana Bonfim ${ }^{3}$, Eny Maria Goloni-Bertollo ${ }^{1}$ \\ Trabalho realizado na Unidade de Pesquisa em Genética e Biologia Molecular - UPGEM, Departamento de Biologia Molecular da Faculdade de Medicina de São \\ José do Rio Preto - FAMERP, São José do Rio Preto, SP
}

\author{
*Correspondence: \\ Unidade de Pesquisa em \\ Genética e Biologia Molecular \\ UPGEM \\ Faculdade de Medicina de São \\ José do Rio Preto - FAMERP \\ Av. Brigadeiro Faria Lima, \\ 5416 - Bloco U-6 \\ São José do Rio Preto - SP, \\ 15090-000 \\ Telefone: (17) 3201-5720 \\ Fax: (17) 3201-5708 \\ erika@famerp.br
}

\begin{abstract}
SUMMARY
ObJective. Considering that studies about the frequencies of phenotypic features of Down syndrome (DS) in the Brazilian population with large ethnic variability are scarce in literature, this study analyzed clinical and demographic characteristics of DS children from the Southeastern region of Brazil.

Methods. Sixty-two DS children with free trisomy 21 were evaluated by physical examination using reference values that considered the children's gender and age at their presentation. Data about clinical complications were collected by retrospective analysis of the children's medical records and/ or information supplied by their mothers. Statistical analysis was performed using Likelihood Ratio Test, with significance level less or equal to $5 \%$.

Results. Clinical features observed in more than $90 \%$ of the individuals were flat facial profile, brachycephaly, slanted palpebral fissures, hypotonia at birth and flat nasal bridge. Congenital heart disease was present in $56.5 \%$ of the cases, verbal language acquisition disorder in $87 \%$, and global delayed development in $77.8 \%$.

ConcLusion. The comparison between our data and related literature showed a great variability of the phenotype features frequencies of DS among studies. Besides environmental factors, this can reflect individual as well as population characteristics.
\end{abstract}

KEYwords: Down syndrome. Phenotype. Physical Examination.

\section{INTRODUCTION}

Down syndrome (DS) is a common chromosomal abnormality, usually due to an extra copy of the 21 . Its incidence is approximately 1:660 live births ${ }^{1}$, and it is the most common genetic cause of mental disability. ${ }^{2,3}$ DS phenotype is complex and varies among individuals, who may present a combination of dysmorphic features, ${ }^{4-6}$ congenital heart disease, ${ }^{7,8,9}$ neurological abnormalities, such as early manifestation of Alzheimer's disease, ${ }^{10}$ immunological deficiency, ${ }^{11}$ and elevated risk of specific types of leukemia, ${ }^{12}$ among other clinical complications. ${ }^{13-15}$.

Diagnostic hypothesis of DS can be performed in the pre and postnatal period and confirmed by chromosome analysis (karyotype examination). Cytogenetic investigation is important to confirm clinical diagnosis and to determinate the recurrence risks of DS, helping the genetic counseling process. ${ }^{16,17}$

Considering that studies about the frequencies of phenotypic features of Down syndrome (DS) in the Brazilian population, that presents a great ethnic variability, are scarce in literature, the objective of this study was to analyze clinical and demographic characteristics of DS children with free trisomy 21 from a teaching hospital linked to a medical school in the Southeastern region of Brazil.

\section{Methods}

This study was approved by the Research Ethics Committee of the São José do Rio Preto Medical School / SP (CEP-FAMERP), and by the National Research Ethics Commission (CONEP), Brazil. All individuals were included in this study only after the Informed Consent of their parents.

The retrospective study was carried out at a general genetics outpatient service of a teaching hospital in Sao José do Rio Preto, São Paulo, Brazil, which assists a region of about 100 municipalities in the Southeast of Brazil. Patients assisted in the general genetics outpatient service usually have a low socioeconomic status.

A sample of 62 DS children with free trisomy 21 in follow-up were included in the study. The clinical evaluation was carried out by physical examination (anthropometric parameters and dysmorphic features), using a detailed protocol of clinical

\footnotetext{
1. Professoras Livre-docentes da Faculdade de Medicina de São José do Rio Preto - FAMERP, São José do Rio Preto, SP

2. Mestre em Ciências da Saúde - Doutoranda em Ciências da Saúde da Faculdade de Medicina de São José do Rio Preto - FAMERP, São José do Rio Preto, SP

3. Enfermeira da Faculdade de Medicina de São José do Rio Preto - FAMERP, São José do Rio Preto, SP
} 
features of DS which is not routinely used at the service. Data regarding brachydactyly, hypertelorism, length of the hands and microcephaly were determined using reference values for non-DS individuals that consider the children's gender and age at their presentation. ${ }^{18}$

Evaluation of weight and height was carried out using specific curves for DS individuals ${ }^{19}$, and these anthropometric data were used to assess the nutritional status of the children by the body mass index for age (BMI-for-age, $\mathrm{Kg} / \mathrm{m}^{2}$ ). The resulting data were plotted in specific charts of BMI for individuals DS ${ }^{19}$. Distribution of indices was expressed in Z-scores terms, also referred to as standard deviation (SD) units, and the Z-score cutoff point to classify low anthropometric levels was 2 SD units below the reference mean.

Data about clinical complications were collected by retrospective analysis of the children's medical records and/ or information provided by their mothers. When an individual was not evaluated for a specific characteristic, he/she was excluded from the frequency analysis of this characteristic. Data concerning age were presented by mean and standard deviation (SD). For statistical analysis of differences between our study and the related literature, the Likelihood Ratio Test (Chi-square test) with a significance level $>5 \%$ was used.

\section{RESULTS}

Of the 62 children included in the study, 27 were female (43.5 \%) and 35 male (56.5\%). The average age at presentation was 3.0 years (range: 0.12 to 12.7 years). In relation to weight and height, $12.3 \%$ and $7.0 \%$ of the individuals presented low and overweight, respectively, while $16.4 \%$ presented low height and $9.1 \%$ presented increased height. Regarding the BMI, $78.2 \%$ of the DS children presented BMI below $18.5 \mathrm{Kg} /$ $\mathrm{m}^{2}$ and $3.6 \%$ above $25 \mathrm{Kg} / \mathrm{m}^{2}$. Analysis of the nutritional status
(BMI-for-age) showed that $16.4 \%$ presented BMI below 2 SD and $10.9 \%$ above 2 SD.

All cases were diagnosed in postnatal period. The average of maternal age at birth of the affected child was $32.0 \pm 8.6$ years (range: 13.1 - 46.9 years). The majority of mothers $(58.1 \%$ ) was under 35 years old at birth of the affected child.

Frequencies of clinical features were presented in Table 1 . The clinical characteristics presented in more than $90 \%$ of individuals were flat facial profile, brachycephaly, slanted palpebral fissures, hypotonia at birth and flat nasal bridge. Verbal language acquisition disorder, and overall delayed development were referred by mothers in $87 \%$ and $77.8 \%$ of cases, respectively.

Clinical complications presented in DS individuals are shown in Figure 1. Congenital heart diseases were represented by interatrial communication (57.1\%), patent ductus arteriosus (34.3\%), interventricular communication (22.9\%), defect of the atrioventricular septum (17.1\%), tetralogy of Fallot (5.7\%), and valve insufficiency (14.3\%). In one case, the problem was not specified. Forty-three percent of children presented more than one type of congenital heart disease.

We performed a comparison among frequencies observed in our study and other studies previously published, and this analysis disclosed significant statistical differences for the majority of characteristics (Table 2).

\section{Discussion}

Three types of chromosomal alterations may result in DS: free trisomy, translocation, and mosaicism. ${ }^{18}$ Advanced maternal age is an important risk factor in free trisomy cases due to imperfections in chromosomal segregation. ${ }^{10-22 . ~ I n ~ t h i s ~ s t u d y, ~}$ most mothers had maternal age under 35 years at birth of their DS child. Occurrence of DS independent of maternal age presents an evidence for other risk factors for this syndrome. More recently,

Figure 1. Clinical complications presented by DS patients. Distribution according to the number of patients evaluated: (1) 59 ; (2) 51 ; (3) 53; (4) 62; (5) 61.

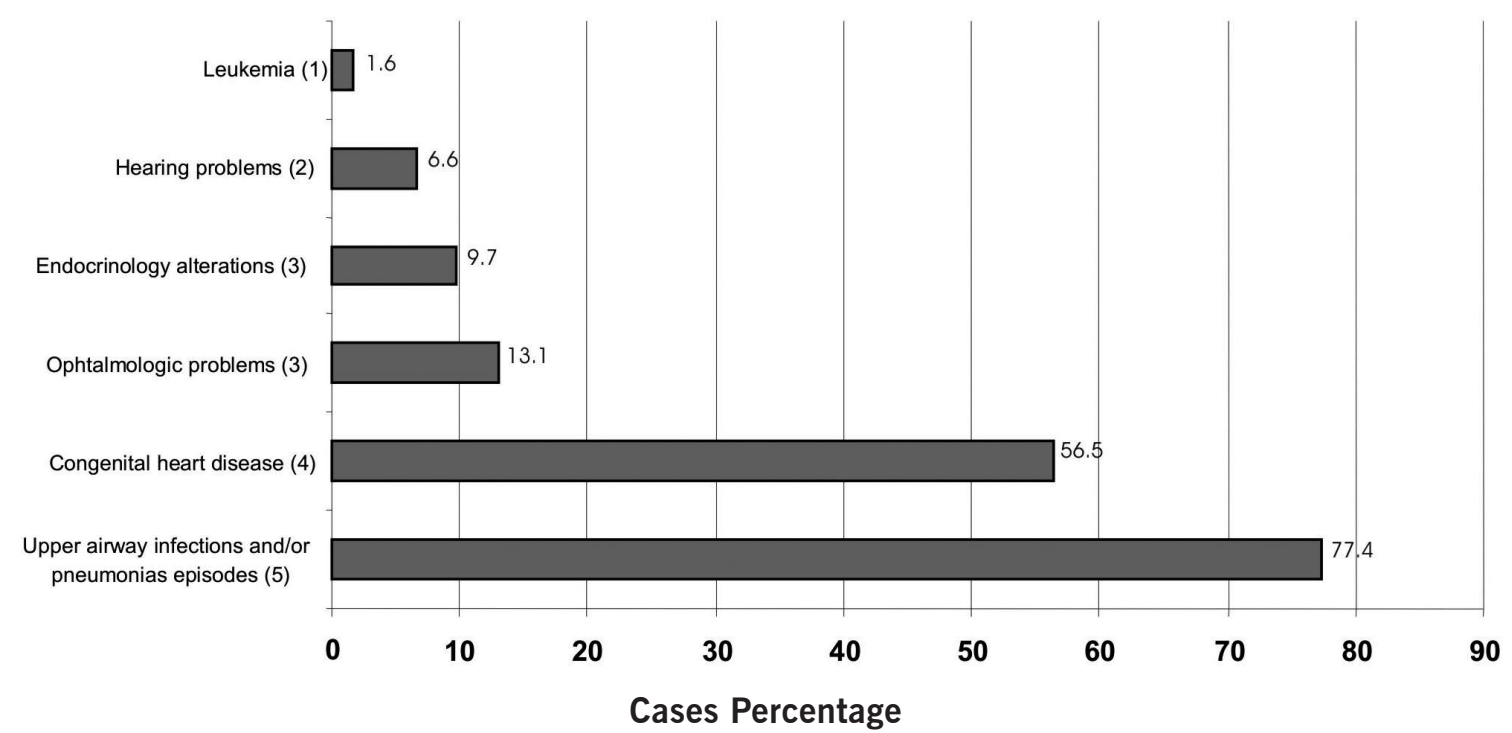




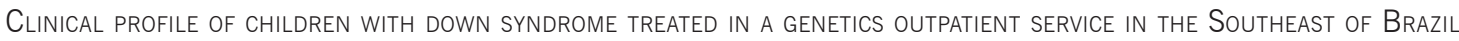

Table 1. Clinical characteristics observed in DS patients.

\begin{tabular}{|c|c|c|}
\hline Characteristics $^{\mathrm{a}}$ & $(\%)$ & $\mathrm{n}$ evaluated \\
\hline Flat facial profile & 98.4 & 62 \\
\hline Brachycephaly & 98.2 & 57 \\
\hline Slanted palpebral fissures; Flat nasal bridge & 93.5 & 62 \\
\hline Hypotonia at birth & 93.4 & 61 \\
\hline Downward-oriented corners of the mouth & 85.5 & 62 \\
\hline Flat occipital; Short neck; Micrognathia; Simian crease & 83.9 & 62 \\
\hline Brachydactyly & 80.6 & 60 \\
\hline Epicanthal folds & 79.0 & 62 \\
\hline Wide neck; Broad hands & 78.7 & 61 \\
\hline Hypertelorism & 72.6 & 62 \\
\hline Cutis marmorata & 70.0 & 60 \\
\hline Small or absence ear-lobes & 69.4 & 62 \\
\hline Short hands & 68.9 & 61 \\
\hline Wide feet & 66.1 & 62 \\
\hline Sandal gap sign & 64.5 & 62 \\
\hline Microcephaly & 60.7 & 61 \\
\hline Ogivale palate & 59.7 & 62 \\
\hline Hypotonia at evaluation date & 59.0 & 61 \\
\hline Slightly open mouth & 47.8 & 62 \\
\hline Clinodactyly & 46.7 & 62 \\
\hline Tooth alterations & 44.7 & $47^{b}$ \\
\hline Plantar crease between first and second toes & 41.9 & 62 \\
\hline Brachydactyly with clinodactyly & 41.0 & 61 \\
\hline Ear dysplasia & 40.3 & 62 \\
\hline High palate & 37.1 & 62 \\
\hline Protruding tongue & 33.9 & 62 \\
\hline Small ears & 32.3 & 62 \\
\hline Umbilical hernia & 25.5 & 61 \\
\hline Nystagmus & 24.2 & 62 \\
\hline Fissured tongue & 19.4 & 62 \\
\hline Strabismus & 16.4 & 61 \\
\hline Low placement of ears & 16.1 & 62 \\
\hline Ear malformation & 14.6 & 61 \\
\hline Nail hypoplasia & 11.5 & 61 \\
\hline Criptorquidia & 11.1 & 35 \\
\hline Abnormal rotation of the ears; Fifth finger mid-phalanx hypoplasia & 9.7 & 62 \\
\hline Syndactyly & 4.8 & 62 \\
\hline Cheilitis & 1.6 & 62 \\
\hline
\end{tabular}

a Characteristics grouped in the same frequency are not necessarily present in the same individual.

${ }^{\mathrm{b}}$ Characteristics evaluated in individuals above 1 year old. 
Table 2. Comparison of clinical characteristics between our study and related literature*

\begin{tabular}{|c|c|c|c|c|c|c|}
\hline Characteristics & $\begin{array}{l}\text { Present study } \\
(\%)\end{array}$ & $\begin{array}{c}\text { Kava et al. } 20045 \\
(\%)\end{array}$ & $\begin{array}{c}\text { Ahmed et al. } 20056 \\
(\%)\end{array}$ & $\begin{array}{c}6 \text { Granzotti et al. } 19957 \\
\text { (\%) }\end{array}$ & $\begin{array}{c}\text { Ribeiro et al. } 200311 \\
(\%)\end{array}$ & P-value \\
\hline Sandal gap sign & 64.5 & 46.2 & 46.4 & & & 0.024 \\
\hline Epicanthal folds & 79.0 & 56.9 & 63 & & & 0.006 \\
\hline Strabismus & 16.4 & 2.7 & 6.4 & & & $<0.0005$ \\
\hline Protruding tongue & 33.9 & 29.9 & & & & 0.7453 \\
\hline Simian crease & 83.9 & 33.2 & 64.7 & & & $<0.0005$ \\
\hline Flat facial profile & 98.4 & 50.9 & & & & $<0.0005$ \\
\hline Hypertelorism & 72.6 & 33.9 & 62.4 & & & $<0.0001$ \\
\hline Hypotonia & 59.0 & 76.3 & 55.9 & & & $<0.0005$ \\
\hline Clinodactyly & 46.7 & 36.1 & 24.7 & & & $<0.0005$ \\
\hline Brachydactyly & 80.6 & 11.1 & 23.7 & & & $<0.0005$ \\
\hline Brachydactyly with clinodactyly & 41.0 & 8.9 & & & & $<0.0005$ \\
\hline Slanted palpebral fissures & 93.5 & 83.9 & 83 & & & 0.18 \\
\hline Flat nasal bridge & 93.5 & & 61 & & & $<0.0005$ \\
\hline Short neck & 83.9 & & 36.7 & & & $<0.0005$ \\
\hline Microcephaly & 60.7 & & 61 & & & 0.9911 \\
\hline Brachycephaly & 98.2 & & 40 & & & $<0.0005$ \\
\hline Congenital heart disease & 56.5 & 18.3 & 34.9 & 51 & 62.2 & $<0.0001$ \\
\hline Short stature & 42.3 & & 21 & & & $<0.0005$ \\
\hline
\end{tabular}

* The comparison between the frequencies observed in this study and other studies was possible with those that present the number of individuals evaluated.

several studies have related the maternal risk for DS with genetic polymorphisms involved in the folate metabolism.17,23-28 DS is responsible for manifestation of a combination of clinical features that makes clinical diagnosis possible. However, some characteristics in frequency and severity are variable among the individuals. $, 5,11,29$. The knowledge of clinical manifestations of DS by physicians and other health professionals is important to make an early postnatal diagnosis possible, since prenatal diagnosis is not frequently performed, as in our sample, where all cases were diagnosed in the postnatal period, with diagnostic hypothesis confirmed by cytogenetic analysis. Late DS diagnosis can result in delayed early intervention and appropriate therapy for some risk conditions, such as congenital heart diseases. These must be detected and treated, otherwise they contribute to morbidity and mortality of these children, in addition, resulting on an impact in the physical and psychological development. ${ }^{5,30}$

Frequencies of DS clinical features vary within the different studies, and some of them described only specific characteristics. Bibliographic reviews on DS have shown a large variability of these frequencies. ${ }^{1,4-8,10-12,16-18,31}$. Comparison of frequencies observed in our study and other studies disclosed significant statistical differences for most characteristics (Table 2). It is possible that the differences may reflect the cytogenetic profile of the individuals included in the study, since in our study only individuals with free trisomy 21 were included while other studies used for comparison evaluated individuals with free trisomy, translocation and mosaicism, even though free trisomy is present in the majority ( $>90 \%$ ) of DS cases, 5,6,18,32 alongside individuals with diagnostic hypothesis of DS without cytogenetic diagnosis. According to Devlin and Morrison 's study ${ }^{1}$, the accuracy of DS clinical diagnosis varies according to the cytogenetic alteration involved (90\% for free trisomy, 100\% for translocation and $37.5 \%$ for mosaicism), apparently reflecting a clinical variability according to cytogenetic abnormality.

Several other factors may contribute to phenotype variability in DS, such as allelic heterogeneity for chromosome 21 genes present in three copies, the individual's genetic constitution and environmental factors. ${ }^{29}$. Brazil is one of the countries with the largest ethnic heterogeneity in the world. This is a result of miscegenation in the immigrant population for centuries, mainly Portuguese, African and Amerindians. This process of miscegenation has provided the gene propagation and contributed to the characteristics of the Brazilian population. Moreover, since Brazil is a country with a large territory, there is a great geographic heterogeneity. ${ }^{33}$

In relation to weight, a higher frequency of low weight (12.3\%) as compared to overweight (7.0\%) was observed in the present study. Regarding the $\mathrm{BMI}$, a high frequency of DS children presented BMI below $18.5 \mathrm{Kg} / \mathrm{m}^{2}$ (78.2\%), while only $3.6 \%$ presented $\mathrm{BMI}$ above $25 \mathrm{Kg} / \mathrm{m}^{2}$. Although obesity is frequent in DS, ${ }^{16}$ the higher frequency of low weight and BMI observed in our study may be explained by the fact that $50 \%$ of the evaluated children presented an age below 2 years old. DS neonates are often born below the usual weight and gain weight as age increases. Analysis of the nutritional status showed that $16.4 \%$ of the children presented undernutrition (BMI-for-age below -2 SD), probably due to the low socioeconomic status of the patients assisted by the general genetics outpatient service of the Hospital de Base de Sao José do Rio Preto. Regarding height, according to literature, ${ }^{34}$ low height is common in DS, and was present in $16.4 \%$ of our DS individuals. 
The incidence of congenital heart diseases in DS is about $60 \% .{ }^{9,35}$ In this study, $56.5 \%$ of the children presented congenital heart diseases, similar frequency in Brazilian studies, which ranges from 51 to $62.2 \% .{ }^{7,11}$

The frequencies of types of congenital heart diseases were similar between our study and Ribeiro et al. ${ }^{11}$ with a greater frequency of interatrial communication in both studies ( $62 \%$ and $46.4 \%$, respectively). In Granzotti et al. 's study, ${ }^{7}$ frequencies of types of congenital heart diseases differ from those observed in our study.

Upper airway infections and/or pneumonia episodes presented a frequency of $77.4 \%$, while in literature this was $50-60 \%$ and $40 \%$, repectively. ${ }^{11}$ DS individuals presented high risk for endocrinology alterations, hearing problems and development of leukemia. ${ }^{12,15,16,31}$ In our study, the mothers reported endocrine alterations and hearing problems in 9.7 and $6.6 \%$, respectively. One case had a diagnosis of acute myeloid leukemia.

Some DS characteristics can be less evident in the individual over the years, 15,36, and environmental factors, such as early stimulation, may also contribute to this change. An example is the difference in frequency of muscular hypotonia at birth (93.4\%) and at evaluation date (59\%), observed in this study. Kava et al. ${ }^{5}$ observed similar frequencies of muscular hypotonia between neonates and non-neonates; however, distinct individuals comprised both groups.

The children included in this study were screened in the Outpatient Service of Genetics of a medical school hospital that offers early stimulation services, such as Phonoaudiology, Physiotherapy, and Occupational Therapy. Other characteristic, the protruding tongue, observed in $33.9 \%$ of the evaluated children, can be modified by earlier stimulation, mainly by Phonoaudiology. Kava et al. ${ }^{5}$ described similar frequency $(29.9 \%)$ in a sample of DS individuals in India. The performance of a multidisciplinary group of health professionals that assist the needs of DS persons and their families, the Ding-Down workgroup, in the medical school - FAMERP, can provide an effective care to DS individuals and family compliance to the programs of earlier stimulation, therefore improving the quality of life of these persons.

\section{Conclusion}

The comparison between our data and related literature showed a great variability of the phenotype features frequencies of DS among studies. In addition to environmental factors, this can also reflect individual and population characteristics.

\section{Financial SUPPort}

Fundação de Amparo à Pesquisa do Estado de São Paulo - FAPESP (04/15944-5); Coordenação de Aperfeiçoamento de Pessoal de Nível Superior - CAPES (CGPP 046/2006); Conselho Nacional de Desenvolvimento Científico e Tecnológico - CNPq (3181/2005); Conselho Nacional de Desenvolvimento Científico e Tecnológico - CNPq (302157/2008-5).

\section{Conflict of interest: none}

\section{Resumo}

\section{Perfil clínico de crianças com síndrome de Down atendidas em um ambulatório de genÉtica NA REgIão Sudeste do BRASIL}

Objetivo. Considerando que estudos relacionados às frequências das características fenotípicas da síndrome de Down (SD) na população brasileira, que apresenta grande variabilidade étnica, são escassos na literatura, este estudo analisou características clínicas e demográficas de crianças com SD da região Sudeste do Brasil.

Métodos. Sessenta e duas crianças com SD com trissomia livre do 21 foram avaliadas por meio de exame físico utilizando-se valores de referência que consideram o gênero e idade da criança na data da avaliação. Dados sobre complicações clínicas foram coletados por análise retrospectiva dos prontuários médicos e/ou informação das mães. A análise estatística foi realizada utilizando-se o teste da razão de máxima verossimilhança com nível de significância menor ou igual a 5\%.

RESUlTADOS. As características clínicas observadas em mais de $90 \%$ dos pacientes foram perfil facial achatado, braquicefalia, fenda palpebral oblíqua, hipotonia muscular ao nascimento e ponte nasal baixa. Doenças cardíacas congênitas estiveram presentes em 56,5\% dos casos, distúrbio de aquisição de linguagem em $87 \%$ e atraso do desenvolvimento global em $77,8 \%$.

Conclusão. A comparação entre nossos dados e a literatura préviamostrougrandevariabilidadedas característicasfenotípicas da SD entre os estudos. Isso pode refletir características individuais e populacionais, além de fatores ambientais. [Rev Assoc Med Bras 2009; 55(5): 547-52]

Unitermos: Síndrome de Down. Fenótipo. Exame físico.

\section{REFERENCES}

1. Devlin L, Morrison P. Accuracy of the clinical diagnosis of Down syndrome. Ulster Med J. 2004;73:4-12.

2. Assumpção Jr FB, Sprovieri MH, Assumpção TM. Deficiência mental em São Paulo: perfil de uma população atendida institucionalmente. Pediatria Moderna 1999;35:883-92.

3. Lantigua-Cruz A, Mora F, Arechaederra M, Rojas I, Morales E, Rodriguez H, et al. Etiological characterization of 512 severely mentally retarded institutionalized patients in Havana. Community Genet. 1999;2:184-9.

4. Prasher VP. Screening of medical problems in adults with Down syndrome. Downs Syndr Res Pract. 1994;2:59-66.

5. Kava MP, Tullu MS, Muranjan MN, Girisha KM. Down syndrome: clinical profile from India. Arch Med Res. 2004;35:31-5.

6. Ahmed I, Ghafoor T, Samore NA, Chattha MN. Down syndrome: clinical and cytogenetic analysis. J Coll Physicians Surg Pak. 2005;15:426-9.

7. Granzotti JA, Paneto ILC, Amaral FTV, Nunes MA. Incidência de cardiopatias congênitas na síndrome de Down. J Pediatr. 1995;71:28-30.

8. Ghaffar S, Lemler MS,Fixler DE,Ramaciotti C. Trisomy 21 and congenital heart disease: effect of timing of initial echocardiogram. Clin Pediatr. (Phila) 2005;44:39-42.

9. Abbag Fl. Congenital heart diseases and other major anomalies in patients with Down syndrome. Saudi Med J. 2006;27:219-22.

10. Lott IT, Head E. Alzheimer disease and Down syndrome: factors in pathogenesis. Neurobiol Aging. 2005;26:383-9.

11. Ribeiro LM, Jacob CM, Pastorino AC, Kim CA, Fomin AB, Castro AP. Evaluation of factors associated with recurrent and/or severe infections in patients with Down's syndrome. J Pediatr. (Rio J) 2003; 79:141-8.

12. Hasle H, Clemmensen IH, Mikkelsen M. Risks of leukaemia and solid tumours in individuals with Down's syndrome. Lancet. 2000;355:165-9.

13. Kriss VM. Down syndrome: imaging of multiorgan involvement. Clin Pediatr. (Phila) 1999;38:441-9.

14. Mackey J, Treem WR, Worley G, Boney A, Hart P, Kishnani PS. Frequency of celiac disease in individuals with Down syndrome in the United States. Clin Pediatr. (Phila) 2001;40:249-52. 
15. Venail F, Gardiner Q, Mondain M. ENT and speech disorders in children with Downs syndrome: an overview of pathophysiology, clinical features, treatments, and current management. Clin Pediatr. (Phila) 2004;43:783-91.

16. Mustacchi Z. Síndrome de Down. In: Mustacchi Z, Peres S. Genética baseada em evidências: Síndromes e Heranças. São Paulo: CID Editora; 2000 p.819-94.

17. Pavarino-Bertelli EC, Biselli JM, Ruiz MT. Recentes avanços moleculares e aspectos genético-clínicos em síndrome de Down. Rev Bras Med. 2005;62:401-8.

18. Jones K B. Smith's Recognizable patterns of human malformations. Philadelphia: WB Saunders; 1998. p.10-5.

19. Myrelid A, Gustafsson J, Ollars B, Annerén G. Growth charts for Down's syndrome from birth to 18 years of age Arch Dis Child. 2002;87:97-103.

20. Hassold T, Sherman S. Down syndrome: genetic recombination and the origin of the extra chromosome 21. Clin Genet. 2000;57:95-100.

21. Jyothy A, Kumar KS, Mallikarjuna GN, Babu Rao V, Uma Devi B, Sujatha $M$, Reddy PP. Parental age and the origin of extra chromosome 21 in Down syndrome. J Hum Genet. 2001;46:347-50.

22. Malini SS, Ramachandra NB. Influence of advanced age of maternal grandmothers on Down syndrome. BMC Med Genet. 2006;14:7-4.

23. Biselli JM, Goloni-BertolloEM, ZampieriBL, Haddad R, Eberlin MN, PavarinoBertelli EC. Genetic polymorphisms involved in folate metabolism and elevated plasma concentrations of homocysteine: maternal risk factors for Down syndrome in Brazil. Genet Mol Res. 2008; 7(1):33-42.

24. Bosco P, Gueant-Rodriguez RM, Anello G, Barone C, Namour F, Caraci F, et al. Methionine synthase (MTR) $2756(\mathrm{~A} \circledast \mathrm{G})$ polymorphism, double heterozygosity methionine synthase $2756 \mathrm{AG} /$ methionine synthase reductase (MTRR) $66 \mathrm{AG}$, and elevated homocysteinemia are three risk factors for having a child with Down syndrome. Am J Med Genet. A 2003;121:219-24.

25. Silva LR, Vergani N, Galdieri Lde C, Ribeiro Porto MP, Longhitano SB, Brunoni D, et al. Relationship between polymorphisms in genes involved in homocysteine metabolism and maternal risk for Down syndrome in Brazil. Am J Med Genet. A 2005; 135:263-7.

26. Martinez-Frias ML, Perez B, Desviat LR, Castro M, Leal F, Rodriguez L, et al. Maternal polymorphisms 677C-T and 1298A-C of MTHFR, and 66A-G MTRR genes: is there any relationship between polymorphisms of the folate pathway, maternal homocysteine levels, and the risk for having a child with Down syndrome? Am J Med Genet. A 2006;140:987-97.
27. Coppede F, Colognato R, Bonelli A, Astrea G, Bargagna S, Siciliano G, et al. Folate gene polymorphisms and the risk of Down syndrome pregnancies in young Italian women. Am J Med Genet. A 2006;140:1083-91.

28. Rai AK, Singh S, Mehta S, Kumar A, Pandey LK, Raman R. MTHFR C677T and A1298C polymorphisms are risk factors for Downs syndrome in Indian mothers. J Hum Genet. 2006;51:278-83.

29. Reeves RH, Baxter LL, Richtmeier. Too much of a good thing: mechanisms of gene action in Down syndrome. Trends Genet. 2001;17 83-8.

30. Hijii T, Fukushige J, Igarashi H, Takahashi N, Ueda K. Life expectancy and social adaptation in individuals with Down syndrome with and without surgery for congenital heart disease. Clin Pediatr. (Phila) 1997;36:327-32.

31. Newberger DS. Down syndrome: prenatal risk assessment and diagnosis. Am Fam Physician. 2000;62:825-32, 837-8.

32. Mokhtar MM, Abd el-Aziz AM, Nazmy NA, Mahrous HS. Cytogenetic profile of Down syndrome in Alexandria, Egypt. East Mediterr Health J. 2003;9:37-44.

33. Parra FC, Amado RC, Lambertucci JR, Rocha J, Antunes CM, Pena SD. Color and genomic ancestry in Brazilians. Proc Natl Acad Sci USA. 2003;100:177-82.

34. Toledo C, Alembik Y, Aguirre Jaime A, Stoll C. Growth curves of children with Down syndrome. Ann Genet. 1999;42:81-90.

35. De Rubens Figueroa J, Del Pozzo Magana B, Pablos Hach JL, Calderon Jimenez C, Castrejon Urbina R. Heart malformations in children with Down syndrome. Rev Esp Cardiol. 2003;56:894-9.

36. Jorde LB, Carey JC, Bamshad MJ, White RL. Citogenética clínica: a base cromossômica das doenças humanas. In: Genética médica. Rio de Janeiro: Guanabara Koogan; 1999. p.97-120.
Artigo recebido: 26/05/08 Aceito para publicação: 17/03/09 